\title{
Identifikasi Variabel yang Berpengaruh terhadap Kinerja Pemasaran dan Indikator Kinerja Pemasaran untuk Industri Hotel
}

\author{
Qurtubi ${ }^{*}$, Dicka Meilana Trisnaningtias, Muhammad Fadhila Yudhanata \\ Jurusan Teknik Industri, Fakultas Teknologi Industri, Universitas Islam Indonesia, Jalan Kaliurang Km. 14,5, Yogyakarta, \\ 55584 , Indonesia
}

\section{ARTICLE INFORMATION}

Article history:

Received: May 14, 2019

Revised: July 14, 2019

Accepted: July 26, 2019

Kata Kunci:

Bauran Pemasaran

Kinerja Pemasaran

Industri Hotel

Keywords:

Hotel Industry

Marketing Mix

Marketing Performance

${ }^{*}$ Corresponding Author

Qurtubi

E-mail: qurtubi@uii.ac.id

\section{A B S T R A K}

Artikel ini membahas penelitian di bidang kinerja pemasaran dengan mengidentifikasi variabel-variabel bauran pemasaran yang berpengaruh terhadap kinerja pemasaran, dan indikator-indikator kinerja pemasaran untuk industri hotel. Tujuan penulisan artikel ini adalah menemukan hubungan bauran pemasaran dengan kinerja pemasaran dan indikator kinerja pemasaran untuk industri hotel. Artikel ini diharapkan dapat menambah wawasan dan berguna untuk penelitian masa depan. Metode yang digunakan dalam penulisan artikel ini adalah studi literatur. Studi literatur dilakukan secara sistematis terhadap 24 artikel penelitian di bidang kinerja pemasaran yang terdapat pada tahun 2000 sampai dengan tahun 2018. Berdasarkan hasil dan pembahasan dapat disimpulkan bahwa variabel-variabel bauran pemasaran yang berpengaruh pada kinerja pemasaran meliputi produk, harga, promosi dan saluran distribusi. Penelitian ini juga menemukan tiga indikator kinerja pemasaran terpilih yang cocok digunakan sebagai indikator kinerja pemasaran di industri hotel. Indikator-indikator tersebut adalah customer mindset, expression of customer preference, dan customer behaviour. Peluang penelitian masa depan antara lain adalah penelitian menggunakan indikator-indikator kinerja pemasaran yang cocok untuk industri-industri jasa lainnya.

\section{A B S T R A C T}

This article discusses marketing performance by identifying marketing mix variables that influence marketing performance and its indicators in the hotel industry. The purpose of this writing was to find the correlation between marketing mix with marketing performance and signs in the hotel industry. This article was expected to extend the insights and provide valuable suggestions for future researches. The method applied in this article was a literature study. The literature study was used systematically towards 24 research articles in the field of marketing performance that written from 2000 to 2018. Based on the results and discussion, it could conclude that marketing mix variables influence marketing performance that covers product, price promotion, and distribution channel. This research also identifies three selected indicators for marketing performance in the hotel industry. Those indicators include customer mindset, expression of customer preference, and customer behavior. The potential future research, among others, is a research that will employ marketing performance indicators that suitable to other service industries.

This is an open access article under the CC-BY-NC-SA license. 


\section{PENDAHULUAN}

Sistem kinerja pemasaran adalah kegiatan yang mencerminkan efisiensi, efektivitas pemasaran dan kemampuan dalam beradaptasi setiap bisnis [1]. Efisiensi adalah pengukuran antara input dan output pada kinerja pemasaran. Efisiensi pemasaran membahas peningkatan rasio input dan output yang dihasilkan, sedangkan efektivitas berhubungan strategi dalam mencapai tujuan organisasi [2].

Untuk menambah wawasan dan pengetahuan mengenai kinerja pemasaran yang berkaitan dengan bauran pemasaran yaitu produk, harga, promosi, dan saluran distribusi, maka peneliti menggali informasi penelitian yang telah dilakukan sebelumnya mengenai hubungan bauran pemasaran dengan kinerja pemasaran dan mengidentifikasi indikator kinerja pemasaran.

Tujuan penulisan artikel ini adalah menemukan hubungan bauran pemasaran dengan kinerja pemasaran, dan indikator kinerja pemasaran untuk industri hotel. Penelitian ini merupakan sebuah studi pendahuluan untuk penelitian yang membahas model pengukuran kinerja pemasaran. Penelitian variabel-variabel bauran pemasaran ini dianggap masih relevan karena pada penelitian selanjutnya dibahas berdasarkan konsep service-dominant logic yang merupakan salah satu pilar teori pemasaran umum. Artikel ini juga diharapkan dapat berkontribusi pada penelitian masa depan, khususnya untuk peneliti yang mengambil topik kinerja pemasaran.

\section{METODE PENELITIAN}

Metode yang digunakan dalam penelitian ini adalah studi literatur. Studi ini dilakukan secara sistematis terhadap 24 artikel penelitian di bidang kinerja pemasaran yang ada pada tahun 2000 sampai dengan tahun 2018. Kurun waktu ini diambil karena terbatasnya jumlah artikel dalam lima tahun terakhir dari sumber yang dipilih. Lingkup artikel yang dipilih adalah artikel dengan topik kinerja pemasaran. Artikel bersumber dari empat online access yakni Science, Proquest, EbscoHost, dan JSTOR. Periode waktu analisis dilakukan adalah pada Bulan Maret dan April 2019. Langkah-langkah yang dilakukan dalam studi literatur ini adalah menyusun artikel berdasarkan tahun penerbitan, melihat isi dan hasil penelitian, mengkategorikan berdasarkan variabel-variabel bauran pemasaran dan mengidentifikasi indikator-indikator kinerja pemasaran, selanjutnya mengambil kesimpulan.

\section{HASIL DAN PEMBAHASAN}

Bagian ini menjelaskan penelitian yang membahas penelitian di bidang kinerja pemasaran, variabel-variabel bauran pemasaran yang berpengaruh terhadap kinerja pemasaran dan mengidentifikasi indikator kinerja pemasaran (Tabel 1).

\section{Penelitian di bidang kinerja pemasaran}

Pada tahun 2000 terdapat dua penelitian. Penelitian pertama oleh Thomas [2] yang mengeksplorasi beberapa masalah akuntabilitas pemasaran. Peneliti mengatakan metode pelaporan keuangan saat ini tidak sesuai dengan perkembangan zaman, peneliti mengusulkan bagaimana pelaporan perusahaan dapat mengembangkan sistem yang benar-benar mencerminkan nilai-nilai perusahaan, sistem pelaporan yang memberikan wawasan nyata tentang nilai-nilai pemangku kepentingan, dan bagaimana investasi pemasaran dan keterampilan pemasaran berkontribusi pada nilainilai tersebut. Penelitian kedua oleh Good dan Stone [3] yang mengemukakan bahwa kinerja ditingkatkan melalui teknologi telah mendorong banyak pemasar untuk mengadopsi sistem komputer. Hasil penelitian menunjukkan bahwa penggunaan komputer yang dikelola dengan baik mampu memperkaya produktivitas pemasar individu dan, pada gilirannya, kinerja organisasi.

Tahun 2003 juga terdapat dua penelitian. Pertama, penelitian Crick, Chaudhry, dan Bradshaw [4] yang membandingkan kinerja bisnis di luar negeri dari dua kelompok perusahaan sukses yang berorientasi teknologi. Hasilnya menunjukkan bahwa meskipun tidak ada perbedaan statistik antara ukuran kinerja kedua kelompok dan sedikit dalam hal sumber daya saing, analisis kualitatif menunjukkan strategi kedua kelompok sangat berbeda. Kedua, penelitian Julian [5] yang menunjukkan empat faktor yang mempengaruhi kinerja pemasaran ekspor adalah persaingan, komitmen (terhadap produk/jasa), karakteristik pasar ekspor (khususnya infrastruktur pasar, tingkat intervensi pemerintah, dan tingkat adaptasi yang diperlukan untuk strategi penentuan posisi suatu produk), dan karakteristik produk (termasuk keunikan, kekhususan budaya, dan karakteristik paten).

Tahun 2006 terdapat satu penelitian yaitu penelitian Eusebio, Andreu, dan Belbeze [6] yang berfokus pada enam kategori langkah-langkah efektivitas pemasaran untuk membandingkan cara mengukur kinerja pemasaran di dua kelompok perusahaan Spanyol (perusahaan 
pariwisata dan perhotelan dan perusahaan industri) dalam studi eksplorasi; dan juga mempelajari pengaruh orientasi bisnis (orientasi pelanggan dan pesaing) pada langkah-langkah yang digunakan untuk mengevaluasi kinerja pemasaran. Hasil yang ditemukan adalah bahwa tindakan berbasis konsumen memiliki peran utama dalam evaluasi efektivitas pemasaran di perusahaan pariwisata dan perhotelan dan orientasi pelanggan mempengaruhi pentingnya tindakan berbasis konsumen ini. Untuk penelitian di masa mendatang, peneliti menyarankan untuk memperbaiki kategori menjadi metrik individual dan mempertimbangkan elemen campuran pemasaran serta pemasaran secara keseluruhan.

Demikian pula pada tahun 2007 dan 2009 masing-masing terdapat satu penelitian, yakni penelitian O'Sullivan [7] yang memberikan wawasan tentang metrik yang digunakan perusahaan Irlandia untuk mengukur kinerja pemasaran. Peneliti memberikan beberapa dukungan untuk hubungan teori antara pengukuran kinerja pemasaran dan kinerja perusahaan. Berdasarkan temuan ini dikemukakan bahwa pengembangan praktik pengukuran kinerja harus dimasukkan dalam program komprehensif untuk meningkatkan kinerja pemasaran. Tantangannya adalah untuk mendorong manajemen puncak untuk memasukkan langkah-langkah non-keuangan, merek, dan tolok ukur dalam penilaian kinerja pemasaran. Penelitian Nwokah [8] menilai pengaruh fokus pelanggan dan fokus pesaing pada kinerja pemasaran organisasi makanan dan minuman di Nigeria. Peneliti memvalidasi instrumen yang ada untuk mengukur fokus pelanggan, fokus pesaing dan kinerja pemasaran. Peneliti juga menemukan hubungan positif yang kuat antara ketiga konstruksi. Menurutnya penelitian masa depan dapat mempertimbangkan pengukuran obyektif atau triangulasi pengukuran subyektif dan obyektif untuk menilai validitas bahwa fokus pelanggan, fokus pesaing mengarah pada kinerja pemasaran.

Sedangkan tahun 2013 terdapat tiga penelitian. Pertama adalah penelitian McManus [9] yang memberikan hasil studi tentang penggunaan dan anteseden akuntansi pelanggan dan ukuran kinerja pemasaran di industri perhotelan Australia. Temuannya memberikan bukti bahwa hotel-hotel besar yang berorientasi pasar dengan struktur terdesentralisasi menggunakan praktik akuntansi dan pemasaran yang berfokus pada pelanggan. Menurutnya penelitian di masa depan mungkin akan diperoleh dari metode yang memungkinkan pengukuran kinerja objektif seperti rasio keuangan, angka profitabilitas atau pendapatan. Selain itu, penelitian di masa depan akan mendapatkan tidak hanya dengan menilai penggunaan teknik-teknik ini tetapi juga untuk memeriksa apakah, dan sejauh mana, informasi customer accounting (CA) diperhitungkan dalam pengambilan keputusan manajemen. Ditambahkannya, penelitian di masa depan dapat dilakukan yang meneliti lebih lanjut semua perusahaan Australia, perusahaan di industri lain atau di mana penggunaan akuntansi dan pemasaran yang berfokus pada langkah-langkah pelanggan mungkin relevan tidak hanya di Australia tetapi juga di negara lain.

Kedua adalah penelitian Frosen, Tikkanen, Jaakkola, dan Vassinen [10] yang mengidentifikasi sembilan dimensi luas kinerja pemasaran yang mendasari sistem marketing performance assesment (MPA) yang digunakan dan lima profil MPA khas perusahaan dari berbagai ukuran di berbagai industri, tahap siklus hidup pasar, dan posisi kompetitif yang terkait dengan berbagai tingkat orientasi pasar dan kinerja bisnis. Temuan penelitian ini mendukung gagasan konseptual yang sebelumnya konseptual dalam MPA dan memberikan bukti empiris untuk faktor-faktor yang mempengaruhi sistem MPA dalam praktik. Hubungan antara berbagai jenis orientasi pasar, dengan fokus yang berbeda ditempatkan pada masing-masing dimensi individu, dan berbagai jenis sistem MPA harus diselidiki lebih lanjut.

Ketiga adalah penelitian Mone, Pop, dan Racolta-Paina [11] yang menawarkan tinjauan yang disintesis, tetapi komprehensif dari literatur manajemen kinerja pemasaran yang relevan. Berdasarkan model produktivitas pemasaran, domain kinerja pemasaran diidentifikasi dan dianalisis, memberikan pendekatan lengkap untuk mengukur dan mengelola kinerja pemasaran, dari strategi pemasaran hingga berdampak pada hasil keuangan. Dalam konteks ini, peneliti memanggil peneliti akademik untuk berkontribusi dengan studi lebih lanjut di bidang ini.

Sama dengan tahun sebelumnya, pada tahun 2014 terdapat tiga penelitian. Penelitian pertama dilakukan oleh Richey, Musgrove, Gillison, dan Gabler [12] yang menyelidiki dampak inisiatif hijau terhadap kinerja perusahaan dan bagaimana komitmen terkait sumber daya berdampak pada efektivitas inisiatif tersebut. Tujuannya adalah untuk mengeksplorasi efektivitas pemasaran hijau pada kinerja 
perusahaan, dalam hal kinerja keuangan, kinerja pasar, dan kualitas layanan. Temuan penelitian ini menunjukkan bahwa komitmen sumber daya yang tepat sangat penting untuk keberhasilan setiap inisiatif hijau. Menurut peneliti, penelitian di masa depan harus memeriksa adaptor dan pengadopsi ini, serta interaksi di antara industri, terutama yang memiliki kompetisi untuk inisiatif lingkungan yang tinggi.

Penelitian kedua dilakukan Jarvinen dan Karjaluoto [13] yang menyelidiki penggunaan analitik web di perusahaan industri, penelitian menunjukkan bahwa upaya organisasi untuk menggunakan sistem metrik pemasaran dan hasil yang dihasilkan tidak dapat dipahami tanpa mempertimbangkan alasan di balik metrik yang dipilih, pemrosesan data metrik, dan konteks organisasi seputar penggunaan sistem. Menurut peneliti, penelitian di masa depan harus menyelidiki bagaimana konteks eksternal organisasi mempengaruhi penggunaan Web Analytics (WA) dan sistem metrik pemasaran lainnya, dan menunjukkan hubungan sebab akibat antara manfaat penggunaan WA dan kinerja perusahaan. Tantangan di masa depan adalah untuk menyatukan "data besar" ini dalam berbagai bentuk, database, dan platform untuk memberikan pemahaman lengkap tentang bagaimana perilaku pelanggan di dunia saat ini dan untuk menilai kinerja pemasaran di lingkungan yang berubah ini.

Penelitian ketiga oleh Choi dan Schellhase [14] yang membahas artikel-artikel dalam edisi khusus Journal of Business Research yang menyediakan berbagai wawasan yang merangsang dan meningkatkan pengetahuan tentang strategi pemasaran dalam lingkungan pemasaran yang kompleks, tidak pasti, dan global. Menurut peneliti, akademisi dan pemimpin bisnis yang berusaha mengembangkan strategi pemasaran berkelanjutan dan meningkatkan kinerja pemasaran mungkin menemukan relevansi dalam topik yang dibahas dalam masalah tersebut.

Sementara itu pada tahun 2016 terdapat empat penelitian. Penelitian pertama oleh Hendrayati dan Gaffar [15] yang mengeksplorasi kinerja pemasaran di industri fashion, serta menganalisis pengaruh inovasi terhadap kinerja pemasaran wirausaha wanita di industri fashion. Peneliti mengatakan, sebagian besar wirausahawan tidak memahami pentingnya memiliki produk asli yang memiliki keunikan. Dalam hal kinerja pemasaran, penjualan dan pertumbuhan pelanggan juga menurun. Ada pengaruh positif antara inovasi kinerja pemasaran womenpreneur di industri fashion. Penelitian kedua oleh Negrut dan Mihartescu [16] yang mengidentifikasi tingkat pelaksanaan fungsi pemasaran di perusahaan kecil dan menengah, di wilayah barat Rumania, untuk mengidentifikasi solusi untuk meningkatkan kinerja ekonomi.

Penelitian ketiga oleh Davcik dan Sharma [17] yang mengidentifikasi dan menggambarkan tiga aliran penelitian yang berbeda terkait dengan sumber daya pemasaran dan kinerja, yaitu hubungan dengan lingkungan perusahaan/ merek, pemasaran sebagai fungsi organisasi dan penyebaran sumber daya pemasaran. Selanjutnya, peneliti membahas kerangka kerja teoritis dan kontribusi artikel penelitian serta makalah yang termasuk dalam masalah khusus ini yang mewakili tiga tema ini. Peneliti mengatakan, beberapa masalah masih tetap belum terselesaikan dan memerlukan lebih banyak perhatian dalam penelitian di masa depan, seperti: Peran Research and Development (R\&D) dan inovasi sebagai kemampuan pemasaran yang dinamis, Peran keunggulan kompetitif berkelanjutan sebagai tujuan strategis bagi perusahaan, Dampak kompetisi intra-perusahaan untuk sumber daya pada keunggulan kompetitif perusahaan, Pengaruh pendekatan 'luar-dalam' versus 'luar-dalam' pada strategi pemasaran, bagaimana Dynamic Marketing Capabilities (DMC) intra-perusahaan mempengaruhi strategi pemasaran, keunggulan kompetitif dan kinerja perusahaan, kepentingan relatif dan pengaruh sumber daya pemasaran pada tingkat produk, merek, portofolio, dan perusahaan dalam memperoleh keunggulan kompetitif. Selain itu menurut peneliti, penelitian di masa depan harus menjawab pertanyaan terbuka yang penting bagi komunitas pemasaran tetapi tidak tercakup oleh lensa teoritis dari kerangka teori paling menonjol di lapangan. Sebagai contoh, bagaimana persaingan antarperusahaan untuk sumber daya dapat mempengaruhi konsumen.

Adapun penelitian keempat oleh Sharma, Davcik, dan Pillai [18] yang menggabungkan teori pensinyalan dan perspektif kemampuan pemasaran dinamis untuk menyelidiki peran peran inovasi produk dalam pengaruh pengeluaran R\&D dan ekuitas merek terhadap kinerja pemasaran. Penelitian ini memberikan wawasan baru ke dalam proses di mana pengeluaran R\&D dan ekuitas merek mempengaruhi inovasi produk dan kinerja pemasaran dalam kategori produk yang sangat kompetitif. penelitian di masa depan dapat mencoba untuk memahami nexus pensinyalan- 
RBT yang berlaku untuk pemasaran. Menurut peneliti, studi di masa depan dapat memperluas penelitian ini dengan menggunakan lingkungan pensinyalan yang berbeda untuk memeriksa, misalnya, fenomena serupa antara organisasi yang berbeda dan termasuk pesaing organisasi pemasaran sebagai penerima sinyal merek yang dimaksudkan atau tidak disengaja. penelitian masa depan melibatkan pengujian dan memperluas keandalan sinyal (selain yang disajikan dalam penelitian ini) untuk kemampuan mereka dalam membantu dengan inovasi produk. Peneliti juga mengatakan, penelitian di masa depan dapat mengidentifikasi kemungkinan variabel alternatif yang memoderasi hubungan ini, seperti tingkat orientasi pasar dari perusahaan yang berinovasi atau sejauh mana keputusan inovasi dipusatkan (yaitu dibuat di kantor pusat) atau didesentralisasi (yaitu, tidak dibuat di lokasi kantor pusat).

Sedangkan pada tahun 2017 terdapat dua penelitian, yaitu Limakrisna, Adriza, dan Zahara [19] yang menentukan dan menganalisis model keunggulan kompetitif dan kinerja pemasaran. Temuan dari penelitian adalah hubungan pembeli, hubungan pemasok, dan sumber daya perusahaan memiliki pengaruh positif dan signifikan terhadap keunggulan kompetitif. Hubungan pembeli berpengaruh dominan secara parsial terhadap keunggulan bersaing. Hubungan pembeli, hubungan pemasok, sumber daya perusahaan, dan keunggulan kompetitif berpengaruh positif dan signifikan terhadap kinerja pemasaran. Sumber daya perusahaan secara parsial berpengaruh dominan terhadap kinerja pemasaran.

Kemudian penelitian Suwandari, Suryana, Wirasasmita, dan Sutisna [20] yang menguji pengaruh orientasi kewirausahaan dan faktor eksternal terhadap penciptaan nilai dan penciptaan nilai terhadap kinerja pemasaran di Usaha Kecil dan Menengah (UKM) Batik. Peneliti menyimpulkan bahwa kinerja pemasaran dapat ditingkatkan dengan penciptaan nilai berdasarkan orientasi kewirausahaan dan dukungan dari faktor eksternal. Upaya pemasaran dengan peninjauan lingkungan melalui konsep green marketing, kasus-kasus tersebut disarankan untuk ditinjau lebih lanjut. Menurut peneliti, hal tersebut belum dijelaskan pada studi saat ini dan berdampak pada kinerja pemasaran.

Penelitian Afriyie, Duo, Appiah, dan Musah [21] menguji silang keterkaitan antara jenis inovasi dan kinerja pemasaran UKM dalam pertumbuhan ekonomi Ghana. Hasil studi peneliti mengidentifikasi manfaat dari dampak yang kuat dan bermakna antara jenis inovasi yaitu Produk, Proses, Pemasaran dan Organisasi dan kinerja pemasaran UKM dari ekonomi berkembang. penelitian ini menawarkan fokus khusus pada jenis inovasi dan hubungannya melalui kinerja pemasaran UKM dalam ekonomi yang sedang berkembang. Peneliti menyarankan, penelitian di masa depan harus didukung untuk menyelidiki hubungan dalam kaitannya dengan empat jenis inovasi dan kinerja pemasaran di sektor manufaktur UKM. Penelitian masa depan ini akan memajukan eksposisi mendalam terkait dengan bagaimana masing-masing jenis inovasi berhubungan satu sama lain dalam kaitannya dengan kinerja pemasaran yang ditingkatkan.

Penelitian Mehrabi, Coviello, dan Ranaweera [22] menjawab pertanyaan apakah menguntungkan memiliki tingkat gabungan eksploitasi dan eksplorasi yang lebih tinggi, haruskah ini seimbang, dan apa faktor internal dan eksternal yang dapat memengaruhi kedua bentuk keramaian ini. Penelitian menemukan bahwa entrepreneurial orientation (EO) secara berbeda mempengaruhi keseimbangan eksplorasieksploitasi dalam customer management (CM) dan new product development (NPD), dalam lingkungan yang dinamis. Peneliti berpendapat, kinerja meningkat ketika ada ambidexterity gabungan yang lebih tinggi di CM dan NPD. Menurut peneliti, penelitian di masa depan dapat mempelajari perusahaan layanan dan membandingkan hasilnya dengan yang diperoleh dalam penelitian ini. Selain itu, penelitian di masa depan dapat memberikan wawasan lebih lanjut dengan mengukur kinerja produk baru menggunakan data objektif seperti jumlah produk baru yang diperkenalkan oleh perusahaan.

Penelitian Nuryakin [23] membahas pengaruh kemampuan pemasaran pada keunggulan kompetitif dan kinerja pemasaran, hubungan antara orientasi pasar pada inovasi produk dan kinerja pemasaran dan memberikan bukti empiris tentang pentingnya keunggulan kompetitif dan inovasi produk untuk meningkatkan kinerja pemasaran yang unggul. Hasil penelitiannya menunjukkan bahwa kemampuan pemasaran memiliki pengaruh yang tidak signifikan terhadap kinerja pemasaran. Kemampuan pemasaran berpengaruh signifikan terhadap keunggulan kompetitif; orientasi pasar berpengaruh signifikan terhadap kinerja pemasaran. Orientasi pasar juga memberi pengaruh signifikan pada inovasi produk. 
Tabel 1. Indikator-indikator kinerja pemasaran

\begin{tabular}{l}
\hline \multicolumn{1}{c}{ Penulis dan tahun } \\
\hline Thomas (2000) \\
Crick, Chaudhry, dan \\
Bradshaw (2003) \\
Eusebio, Andreu, dan Belbeze \\
(2006) \\
O'Sullivan (2007)
\end{tabular}

Nwokah (2009)

Mone, Pop, dan Racolta-Paina (2013)

McManus (2013)

Jarvinen dan Karjaluoto

(2015)

Hendrayati dan Gaffar (2016)

Limakrisna, Adriza, dan

Zahara (2017)

Suwandari,

Suryana, Wirasasmita, dan

Sutisna (2017)

Afriyie, Duo, Appiah, dan

Musah (2018)

Mehrabi, Coviello, dan

Ranaweera (2018)

Nuryakin (2018)

Indikator kinerja pemasaran

Sales performance, Profit performance, Market share performance, Brand Strength performance, Customer retention

Performance, Customer acquisition Performance

Sales volume, Sales growth, Market share, Profitability

Financial, competitive market, Consumer behaviour, Consumer intermediate, Direct customer, Innovativeness

Sales growth, Profitability, New product success, Percentage of sales share accounted for by new products, Market share and $\mathrm{ROI}, \mathrm{ROA}$

Finance, Competitive market, Consumer behavior, Consumer intermediaries, Direct customer, Innovativeness

Activity indicators, Operational indicators, Outcome indicators, Leading Indicators, Predictive Indicators

Financial performance, Non financial performance

Sales leads growth, Profit through sales leads, Number of sales leads, Sales revenue through sales leads, Website visit growth

Manifested in strong brand awareness, Expression of customer preferences, The high level of market share

Sales volume, Sales growth, Market share, Profitability, Cash flow, Sales units, Efficiency, New customers

Selling growth and selling volume, Market segment

Customer mindset, Product-market performance, Accounting performance, Financial market performance

Entrepreneurial orientation, Customer relationship performance

Sales volume, Profit growth, Asset growth, Customer's growth

Inovasi produk berpengaruh signifikan terhadap keunggulan kompetitif. Keunggulan kompetitif berpengaruh signifikan terhadap kinerja pemasaran dan inovasi produk berpengaruh signifikan terhadap kinerja pemasaran. Peneliti merekomendasikan untuk penelitian di masa depan, perlu untuk mengembangkan pengembangan model yang lebih komprehensif tentang karakteristik internal pengusaha UKM; untuk contoh orientasi kewirausahaan, kemampuan belajar dan fleksibilitas relasional untuk meningkatkan kinerja pemasaran secara terus menerus. Kemudian rekomendasi lain terkait dengan sampel penelitian, sampel yang digunakan harus lebih selektif dalam memilih responden mengingat karakteristik responden yang sangat heterogen yang dapat mengarah pada tanggapan yang bias.

\section{Hubungan produk dan harga dengan kinerja pemasaran}

Pengembangan inovasi produk serta keunggulan kompetitif mempunyai peranan yang penting untuk meningkatkan kinerja pemasaran di sebuah perusahaan [23]. Dalam penelitiannya disebutkan, pengusaha UKM di Indonesia harus menciptakan sebuah inovasi produk baik dalam segi desain, pemilihan bahan baku yang berkualitas, pembuatan motif yang mencerminkan budaya serta penggunaan warna yang menarik sehingga dapat menjadi nilai jual yang tinggi dan menjadi daya saing di pasaran. Penelitian Afriyie, Duo, Appiah, dan Musah [21] 
juga mengatakan, semua jenis inovasi mempunyai pengaruh positif bagi kinerja pemasaran. Selain itu peneliti menyebutkan, inovasi pemasaran juga mempunyai pengaruh yang berdampak pada kinerja pemasaran dengan semua inovasi produk yang mempengaruhi kinerja.

Demikian pula penelitian Hendrayati dan Gaffar [15] mengatakan hal yang sama, pada industri fashion wanita inovasi produk masih sangat kurang sehingga menyebabkan kinerja pemasaran, penjualan dan pertumbuhan pelanggan menurun. Di samping itu industri fashion lebih menonjolkan fashion versi produk luar negeri, padahal menciptakan produk yang original dengan berbagai macam keunikan serta inovatif jauh lebih mendukung dan memenangkan persaingan di pasaran. Selain memperhatikan adanya penciptaan inovasi produk, peningkatan nilai dari suatu produk (value creation) juga harus diperhatikan untuk meningkatkan minat bagi pelanggan. Nilai produk yang diciptakan bisa berupa nilai yang mencerminkan kebudayaan atau seni tradisional sehingga mempunyai kesan dan cerita ketika pelanggan membeli produkproduk tersebut, juga dapat memiliki nilai harga produk yang bervariasi seperti dari harga wajar, harga yang konsisten serta harga yang dapat memberi keuntungan bagi pelanggan [20].

Selain itu terdapat penelitian Davcik dan Sharma [17] yang mengatakan pentingnya dilakukan suatu persaingan produk yaitu melalui strategi merek, pelaku pasar juga harus melakukan strategi diferensiasi produk yang berbeda melalui penciptaan inovasi agar dapat memperoleh pangsa pasar yang tinggi. Dalam penelitian ini juga membahas tentang adanya teori pensinyalan yaitu perusahaan membuat sebuah janji kepada konsumen berdasarkan nilai merek produknya tetapi pihak perusahaan tidak memberi kejelasan bagaimana sumber daya mereka dapat memenuhi janji dalam kinerja tersebut. Dengan adanya teori pensinyalan ini dapat memberikan dasar dalam penelitian bagi manajer pemasaran dalam memutuskan faktor mana yang menjadi fokus agar membuat keputusan inovasi produk yang lebih baik.

\section{Hubungan promosi dan saluran distribusi dengan kinerja pemasaran}

Rantai pasok berkaitan dengan proses pengadaan bahan baku, pergerakan dan penyimpanan barang serta di dalamnya termasuk arus informasi yang terkait melalui saluran distribusi dan promosi pada pemasaran untuk memaksimalkan keuntungan [24]. Pada dasarnya pembahasan promosi dan saluran distribusi adalah mengenai pemilihan lokasi yang strategis dan menjadi salah satu faktor yang mempengaruhi kesuksesan pemasaran. Semakin strategis lokasi usaha yang dipilih, semakin tinggi pula tingkat penjualan dan berpengaruh terhadap kesuksesan sebuah usaha. Hal tersebut sebagai akibat kemudahan akses dan ketersediaan produk, karena tujuan dari distribusi sendiri ialah menyediakan produk dan jasa kepada konsumen pada tempat dan waktu yang tepat. Sedangkan promosi berkaitan dengan cara berkomunikasi langsung dan tidak langsung dengan calon konsumen. Di dalamnya termasuk untuk mengetahui produk yang diinginkan konsumen, tingkat kebutuhan konsumen akan suatu produk, cara penyampaian produk hingga sampai ke konsumen, harga yang sesuai dengan kondisi pasar, dan menciptakan merek sebuah produk dengan adanya promosi.

Tabel 2. Dasar hubungan bauran pemasaran terhadap kinerja pemasaran

\begin{tabular}{ll}
\hline Bauran pemasaran & \multicolumn{2}{c}{ Penulis } \\
\hline Produk dan harga & Hendrayati dan Gaffar \\
& {$[15] ; \quad$ Suwandari, } \\
& Suryana, Wirasasmita, \\
& dan Sutisna [20]; \\
& Afriyie, Duo, Appiah, \\
& dan Musah [21]; \\
& Nuryakin [23] \\
& \multicolumn{1}{c}{ McManus [9]; Nuryakin } \\
Promosi dan saluran & [23], Liu, Yuan, Hafeez, \\
distribusi & dan QYuan [24] \\
\hline
\end{tabular}

Tabel 2 menunjukkan tulisan yang menjadi dasar adanya hubungan variabel-variabel bauran pemasaran terhadap kinerja pemasaran. Penelitian Nuryakin [23] memasukkan indikator kemampuan untuk mempromosikan produk di dalam pengukuran kinerja pemasaran dan hasilnya membuktikan bahwa orientasi pasar memberikan pengaruh yang signifikan terhadap kinerja pemasaran dan inovasi produk. Dalam penelitian McManus [9] juga ditegaskan bahwa ketika manajer pemasaran menggunakan informasi pemasaran untuk pengambilan keputusan. Di dalam industri hotel pada aspek pemasaran tidak hanya membutuhkan lebih banyak informasi, tetapi juga cenderung lebih menekankan pada informasi eksternal sebagai cara untuk menghadapi penekanan yang lebih besar. Sehingga di dalam penelitiannya, para manajer menempatkan posisi strategis hotelnya dibandingkan dengan para pesaingnya. Diantaranya menyebutkan salah satu hotel 
mencari dan mempertahankan posisi yang aman di wilayah layanan yang relatif stabil. Hal tersebut berkaitan untuk menawarkan jangkauan layanan yang lebih terbatas dan stabil daripada pesaing. Ada juga hotel yang dalam pengembangan layanan cenderung menawarkan jangkauan layanan yang lebih luas dari pada perusahaan lain dengan ukuran yang sama di industri perhotelan.

\section{Indikator kinerja pemasaran}

Tabel 3 menunjukkan artikel yang menjadi dasar indikator kinerja pemasaran terpilih yang dapat digunakan pada penelitian berikutnya mengenai model pengukuran kinerja pemasaran. Dipilih tiga indikator ini berdasarkan pertimbangan objek penelitian selanjutnya adalah industri hotel, sehingga yang dipilih merupakan indikatorindikator yang cocok untuk industri jasa.

Tabel 3. Tiga indikator kinerja pemasaran terpilih

\begin{tabular}{ll}
\hline Indikator kinerja pemasaran & \multicolumn{1}{c}{ Penulis } \\
\hline Customer mindset & $\begin{array}{l}\text { Afriyie, Duo, } \\
\text { Appiah, dan } \\
\text { Musah [21] }\end{array}$ \\
& $\begin{array}{l}\text { Hendrayati } \\
\text { dan Gaffar }\end{array}$ \\
pxpression of customer & {$[15]$} \\
& Eusebio, dan \\
Customer behaviour & Andreu, dan \\
& Belbeze [6]; \\
& Nwokah [8] \\
\hline
\end{tabular}

\section{KESIMPULAN}

Berdasarkan hasil dan pembahasan dapat ditunjukkan variabel-variabel bauran pemasaran yang berpengaruh pada kinerja pemasaran. Penelitian ini juga berhasil mengidentifikasi indikator kinerja pemasaran terpilih yaitu customer mindset, expression of customer preference, dan customer behaviour yang dapat digunakan sebagai dasar untuk penelitian selanjutnya mengenai model pengukuran kinerja pemasaran di industri hotel. Peluang penelitian masa depan antara lain adalah penelitian menggunakan indikator kinerja pemasaran yang cocok untuk industri-industri jasa lainnya.

\section{DAFTAR PUSTAKA}

[1] T. Ambler, F. Kokkinaki, and S. Puntoni, "Assessing Marketing Performance: Reasons for Metrics Selection," J. Mark. Manag., vol. 20, no. 3-4, pp. 475-498, Apr. 2004 , doi:
[2] M. J. Thomas, "Marketing performance measurement: Directions for development," J. Targeting, Meas. Anal. Mark., vol. 9, no. 1, pp. 70-91, Aug. 2000, doi: 10.1057 /palgrave.jt.5740006.

[3] D. J. Good and R. W. Stone, "The impact of computerization on marketing performance," J. Bus. Ind. Mark., vol. 15, no. 1, pp. 34-56, Feb. 2000, doi: 10.1108/08858620010311548.

[4] D. Crick, S. Chaudhry, and R. Bradshaw, "The overseas marketing performance of successful small UK high-technology firms: an exploratory study comparing indigenous and subsidiary firms' competitiveness," Strateg. Chang., vol. 12, no. 8, pp. 421-433, Dec. 2003, doi: 10.1002/jsc.653.

[5] C. C. Julian, "Export Marketing Performance: A Study of Thailand Firms," J. Small Bus. Manag., vol. 41, no. 2, pp. 213-221, Apr. 2003, doi: 10.1111/1540$627 X .00077$.

[6] R. Eusebio, J. Llonch Andreu, and M. Pilar López Belbeze, "Measures of marketing performance: a comparative study from Spain," Int. J. Contemp. Hosp. Manag., vol. 18, no. 2, pp. 145-155, Feb. 2006, doi: 10.1108/09596110610646691.

[7] D. O Sullivan, "The measurement of marketing performance in Irish firms," Irish Mark. Rev., vol. 19, no. 1/2, p. 26, 2007, available http://lok8.dit.ie/media/newsdocuments/20 08/neweditionofirishmarketingreview/030 Sullivan.pdf.

[8] N. G. Nwokah, "Customer-focus, competitor-focus and marketing performance," Meas. Bus. Excell., vol. 13, no. 3, pp. 20-28, Aug. 2009, doi: 10.1108/13683040910984293.

[9] L. McManus, "Customer accounting and marketing performance measures in the hotel industry: Evidence from Australia," Int. J. Hosp. Manag., vol. 33, pp. 140152, Jun. 2013, doi: 10.1016/j.ijhm.2012.07.007.

[10] J. Frösén, H. Tikkanen, M. Jaakkola, and A. Vassinen, "Marketing performance assessment systems and the business context," Eur. J. Mark., vol. 47, no. 5/6, pp. 715-737, May 2013, doi: 10.1108/03090561311306688.

[11] S.-D. Mone, M. D. Pop, and N.-D. Racolta-Paina, "The 'what' and 'how' of marketing performance management," Manag. Mark., vol. 8, no. 1, pp. 129-146, 2013, available at: 
http://www.managementmarketing.ro/hom e.php?var[1]=1\&var[3]=2013\&var[2]=305.

[12] R. G. Richey, C. F. Musgrove, S. T. Gillison, and C. B. Gabler, "The effects of environmental focus and program timing on green marketing performance and the moderating role of resource commitment," Ind. Mark. Manag., vol. 43, no. 7, pp. 1246-1257, Oct. 2014, doi: 10.1016/j.indmarman.2014.06.014.

[13] J. Järvinen and $H$. Karjaluoto, "The use of Web analytics for digital marketing performance measurement," Ind. Mark. Manag., vol. 50, no. 1, pp. 117-127, Oct. 2015, doi: 10.1016/j.indmarman.2015.04.009.

[14] Y. K. Choi and R. Schellhase, "Exploring globalization and marketing performance at the 2012 Global Marketing Conference at Seoul," J. Bus. Res., vol. 67, no. 10, pp. 2053-2055, Oct. 2014, doi: 10.1016/j.jbusres.2014.04.012.

[15] H. Hendrayati and V. Gaffar, "Innovation and Marketing Performance of Womenpreneur in Fashion Industry in Indonesia," Procedia - Soc. Behav. Sci., vol. 219, pp. 299-306, May 2016, doi: 10.1016/j.sbspro.2016.04.034.

[16] M. L. Negrut and A.-A. Mihartescu, "Market Study on Performance of the Marketing Function in Small and Medium Enterprises in Romania," Procedia - Soc. Behav. Sci., vol. 221, no. 1, pp. 119-125, Jun. 2016, doi: 10.1016/j.sbspro.2016.05.097.

[17] N. S. Davcik and P. Sharma, "Marketing resources, performance, and competitive advantage: A review and future research directions," J. Bus. Res., vol. 69, no. 12, pp. 5547-5552, Dec. 2016, doi: 10.1016/j.jbusres.2016.04.169.

[18] P. Sharma, N. S. Davcik, and K. G. Pillai, "Product innovation as a mediator in the impact of R\&D expenditure and brand equity on marketing performance," J. Bus. Res., vol. 69, no. 12, pp. 5662-5669, Dec. 2016, doi: 10.1016/j.jbusres.2016.03.074.

[19] N. Limakrisna and R. Zahara, "Determinant of Pharmaceutical Industries Marketing Performance in Indonesia," Int. Rev. Manag. Mark., vol. 7, no. 3, pp. 274 280, 2017, available at: https://dergipark.org.tr/irmm/issue/32110/ 356019.

[20] L. Suwandari, Y. Suryana, and Y. Wirasasmita, "Marketing Performance of Batik Tulis based of Entrepreneurship Orientation in Daerah Istimewa
Yogyakarta SME's," Acad. Strateg. Manag. J., vol. 16, no. 3, pp. 1-15, 2017, available https://www.abacademies.org/articles/Mar keting-performance-of-batik-tulis-basedof-entrepreneurship-orientation-in-daerahistimewa-yogyakarta-smes-1939-6104-163-119.pdf.

[21] S. Afriyie, J. Duo, K. Appiah, and A. I. Musah, "The Nexus between types of innovation and marketing performance of SME in an emerging economy," Int. Rev. Manag. Mark., vol. 8, no. 6, pp. 78-92, 2018, available at: https://ideas.repec.org/a/eco/journ3/201806-12.html.

[22] H. Mehrabi, N. Coviello, and C. Ranaweera, "Ambidextrous marketing capabilities and performance: How and when entrepreneurial orientation makes a difference," Ind. Mark. Manag., vol. 77, no. 1, pp. 129-142, Feb. 2019, doi: 10.1016/j.indmarman.2018.11.014.

[23] U. M. Y. Nuryakin, "Competitive advantage and product innovation: Key success of Batik SMEs marketing performance in Indonesia," Acad. Strateg. Manag. J., vol. 17, no. 2, pp. 1-17, 2018, available at: https://www.abacademies.org/articles/Co mpetitive-advantage-and-productinnovation-1939-6104-17-2-201.pdf.

[24] J. Liu, C. Yuan, M. Hafeez, and Q. Yuan, "The relationship between environment and logistics performance: Evidence from Asian countries," J. Clean. Prod., vol. 204, pp. 282-291, Dec. 2018, doi: 10.1016/j.jclepro.2018.08.310. 